\title{
THE RIGHTS TO REVIEW POLICY RULES IN THE PERSPECTIVE OF RULE OF LAW
}

\author{
Ida Hanifah*, Andryan* \\ *Universitas Muhammadiyah Sumatera Utara, Medan \\ Corresponding author: idahanifah@umsu.ac.id \\ Received on: 26-07-2021; Revised on: 16-08-2021; Approved to be published on: 03-09-2021 \\ DOI: http://dx.doi.org/10.30641/dejure.2021.V21.321-330
}

\begin{abstract}
The State of Indonesia is a country based on law, this is as confirmed in Article 1 paragraph (3) of the 1945 Constitution, the State of Indonesia is a rule of law. Policy rules only function as part of the operational implementation of government tasks. This research used normative juridical research method, namely research in which the study refers to and bases on legal norms and rules. The statutory approach was used to look at the issue of the right to review policy rules. The conceptual approach was used to look at the conception of reviewing policy rules in the concept of rule of law. Policy rules are not a type of laws and regulations, the right to review laws and regulations cannot be applied to policy rules. The review of policy rules is more directed at doelmatigheid and the touchstone is the general principles of proper governance. The Supreme Court cannot review policy rules. Arrangements are needed to realize the protection for the parties who are harmed due to a policy rule, so that it can be in accordance with the concept of rule of law.
\end{abstract}

Keywords: review; policy rules; rule of law

\section{INTRODUCTION}

The State of Indonesia is a country based on law, this is as confirmed inArticle 1 paragraph (3) of the 1945 Constitution of the Republic of Indonesia (UUD 1945), "The State of Indonesia is a rule of law". One of the logical consequences of a state based on law is that all rules must be based on law. In relation to legal rules, the legal rules in the form of a sequence of laws and regulations becomes the foundation in the implementation of government activities. Because with the hierarchical order of laws and regulations, it will make it easier for law enforcement and the existence of law order. Laws and regulations as one of the main elements in the national legal system. As a system, the rules contained in all forms of law are arranged hierarchically and culminated in the Constitution as the supreme law. Lower laws and regulations must not conflict with higher regulations. If that happens, then the legal principle of Lex spesialis derogat legi inferiori shall apply.

In the provisions of Law No. 12 Year 2011 in conjunction with Law Number 15 Year 2019 concerning Amendment to Law Number 12 Year 2011 concerning the Establishment of Laws and Regulations, Article 7 states that the types and hierarchy of laws and regulations are the
1945 Constitution of the Republic of Indonesia, Decree of the People's Consultative Assembly, Laws/Government Regulations in Lieu of Laws, Government Regulations, Presidential Regulations, Provincial Regulations, and Regency/ Municipal Regulations.

Article 8 paragraph (1) essentially emphasizes that laws and regulations also include regulations stipulated by the People's Consultative Assembly (MPR), the House of Representatives (DPR), the Regional House of Representatives (DPD), the Supreme Court (MA), the Constitutional Court (MK), the Supreme Audit Agency (BPK), the Judicial Commission (KY), the Bank Indonesia (BI), Ministries, or the same commissions established by the government and institutions established by the government, regional heads such as the Governor, Regent/Mayor and Provincial, Regency/Municipal DPRD (Regional House of People's Representatives).

The ideals of the state will be realized if there is order and law and they will only be realized if there are legal rules that command, so that law can be established as a system. If there are laws and regulations that conflict with each other, the state shall ensure that the laws and regulations do not contradict each other based on the order 
or hierarchy, that is, by reviewing the laws and regulations. The review of laws and regulations has existed since 1970 through the enactment of Law No. 14 Year 1970, on judicial principles, and continuously being explicitly regulated in the third amendment of the 1945 Constitution of the Republic of Indonesia, and it is the process of conflicting one rule with another so that there is still normative coherence and harmonization.

The authority to review laws and regulations is given to two institutions with different positions. Article 9 paragraphs (1) and (2) of Law No. 12 Year 2011 states that first, if the law contradicts the 1945 Constitution of the Republic of Indonesia, then it becomes the authority of the Constitutional Court, and secondly, if the laws and regulations under the law contradict, they will be reviewed by the Supreme Court. In the constitutional system in Indonesia, in addition to related policies (beleids gebonden) based on Law No. 12 Year 2011 in conjunction with Law No. 15 Year 2019, on the basis of freies emersen, state administration officials can make free policies (vrijheleid).

In carrying out the tasks of state administration, the government issues many policies that are outlined in various forms such as policy lines, regulations, guidelines, directions, circulars, resolutions, instructions, policy notes, regulations, ministerial regulations, decrees, announcements. ${ }^{1}$

Philipus M. Hadjon states that policy rules are essentially a product of state administrative actions aimed at "naar buiten gebracht scrichftelijk beleid", which is to reveal a written policy. ${ }^{2}$ Policy rules serve as the basis for implementing government duties so that they must comply with applicable laws and regulations. Bagir Manan argues that policy rules cannot be reviewed (wetmatigheid) on the grounds of the existence of laws and regulations to issue policy rules and the absence of the relevant administrative authority to make laws and regulations on the basis of freies ermessen. $^{3}$

\footnotetext{
Ridwan HR, Hukum Administrasi Negara (Jakarta: Rajagrafindo Persada, 2006).

2 Philipus M. Hadjon, Pengantar Hukum Administrasi Indonesia (Yogyakarta: Gajah Mada University Press, 1993).

3 Bagir Manan, "Peraturan Kebijakan”, Varia Peradilan, Volume I Tahun 2008, hlm. 16-17.
}

The Supreme Court has made a breakthrough in reviewing a policy rule in the form of a circular, namely Circular of the Director General of Minerals, Coals and Geothermal Number 03/31/ DJB/2009 (SE No. 03/31/DJB/2009). Based on the Decision of the Supreme Court of the Republic of Indonesia on Case No. 23 P/HUM/2009, the Supreme Court stated that SE No. 03/31/ DJB/2009 (SEPPMB) is contrary to Law Number 4 Year 2009 concerning Mineral and Coal Mining. Based on this decision, the policy rule is declared invalid and does not apply to the public. The Supreme Court's decision shows that there is an interpretation that expands the scope of the types of laws and regulations. So that it will be studied regarding the position of policy rules and what the rights to review policy rules are in the perspective of rule of law.

There are several writings and studies that talk about policy rules, namely:

1. "Judicative Authority in Reviewing Policy rules", written by Victor Immanuel W. Nalle in the Judicial Journal. This paper describes the basis of authority of the judicative institutions in conducting review of laws and regulations, namely the Constitutional Court and the Supreme Court.

2. "The Position of Policy rules in Government Administration Law", written by Victor Immanuel W. Nalle in the Journal of Legal Reflections. This paper only describes the position of policy rules according to the Government Administration Law. As in Law Number 30 Year 2014 concerning Government Administration as a legal umbrella for government administration which does not regulate the position of policy rules.

3. "Legal Position of Regulations/Policies Under Regulation of the Minister of National Development Planning/Head of Bappenas", written by Arif Cristiono Soebroto on the bappenas.go.id website. In this paper, the author describes the types of state regulations, the history and basis of the authority to establish laws and regulations as well as the legal position of regulations/policies under Ministerial Regulations.

Based on the descriptions of the writings and research above, this paper has differences with previous writings. This paper does not 
only describe the position of policy rules in the statutory system, but also describes how in a rule of law, regarding the protection of actions made through policy rules, it is very urgent to make regulations, especially regarding the process of reviewing policy rules. Therefore, the researcher deemed that this paper has a novelty.

\section{RESEARCH METHOD}

Legal research is actually related to how to understand the law (what is the law? How to understand the law?) and how to know the sources of law. ${ }^{4}$ The research method used is normative juridical, to get answers to the problem of the right to review policy rules in the perspective of rule of law. This research used a qualitative doctrinal approach based on secondary data. ${ }^{5}$ Terry Hutchinson distinguishes legal research from doctrinal research, the category that regulates certain legal categories, analyzes the rules of relations, describes, and predicts possible future developments, research which generally suggests assessing the existing rules and recommends changes to inadequate rules. ${ }^{6}$ The statutory approach was used to look at the issue of the right to review policy rules. The conceptual approach was used to look at the conception of reviewing policy rules in the concept of rule of law. Therefore, the development of the interpretation of the right to review policy rules in the perspective of rule of law was analyzed qualitatively and descriptively. The materials used in this research are primary materials, which include the applicable laws and regulations and jurisprudence relating to the subject matter of this research. Secondary materials consist of the results of previous research related to this research problems, literature, including materials and results of seminars and conferences.

4 Ahyar Ari Gayo, "Optimalisasi Pelayanan Bantuan Hukum Bagi Masyarakat Miskin,” Jurnal Penelitian Hukum De Jure 20, no. 409-432 (2020).

5 Andryan Farid Wajdi, "Sifat Putusan Impeachment Mahkamah Konstitusi Terhadap Status Hukum Presiden Dan/Atau Wakil Presiden," Jurnal Penelitian Hukum De Jure 20, no. 3 (2020): 301-313.

6 Eka NAM Sihombing Chandranegara, Ibnu Sina, "EMERGENCY LAW-MAKING IN INDONESIA: BETWEEN POLITICAL AND CONSTITUTIONAL PROCESS," Journal of Legal, Ethical and Regulatory Issues 24, no. 4 (2021): 1-7.
Tertiary materials consist of legal dictionaries, encyclopedias and other supporting dictionaries. ${ }^{7}$

\section{DISCUSSION}

\section{A. The Right to Review Legal Norms}

Hans Kelsen with the theory of legal levels (Stufentheorie) argues that:

'The 'grundnorm' is not constitution, it is simply the presupposition, demanded by theory, that this constitution ought to be obeyed. ${ }^{8}$ (Basic Norm is the highest norm in a system of norms, it is no longer formed by a higher norm, but the Basic Norm is determined in advance by the society as a Basic Norm which is a hanger for the norms that are under it, so that a Basic Norm is said to be pre-supposed). ${ }^{9}$

According to Hans Kelsen, legal norms are always sourced and based on the norms above them, but the legal norms also become the source and the basis for norms lower than them. Hierarchically, there is a system of norms that must be obeyed, the lowest norm will depend on the norm above it, and the norm will depend on the norm above it again. ${ }^{10}$

Hans Nawiasky developed Hans Kelsen's theory about the level of norms in relation to legal norms of any country which is always layered and tiered. The norms below are valid, sourced and based on the higher norms; the higher norms are valid, sourced and based on a highest norm, which is referred to as the basic norm. ${ }^{11}$

The division of the subject and object of regulation causes a review of legal norms. Regarding the subject of review, there are review by judges, review by the legislature and review by

7 Marulak Pardede, "Legitimasi Pemilihan Kepala/ Wakil Kepala Daerah Dalam Sistem Pemerintahan Otonomi Daerah," Jurnal Penelitian Hukum De Jure 18, no. 2 (2018): 127-147.

8 RWM Dias, Jurispredence (London: Butterworths, 1985).

9 Maria Farida Indrati Soeprapto, Ilmu PerundangUndangan: Jenis, Fungsi Dan Materi Muatan (Yogyakarta: Kanisius, 2010).

1 Ibid.

" Eka NAM Sihombing, "Menyoal Ketentuan Usul Pindah Pegawai Negeri Sipil Di Lingkungan Pemerintah Daerah Kabupaten Nias Barat," Jurnal Penelitian Hukum De Jure 16, no. 1 (2016): 95-104. 
the executive. ${ }^{12}$ In terms of the right to review, as in the literature in the Netherlands, the true review is divided into two, namely the formal review (formele toetsubfsrecht) and the material review (materiele toetsingsrecht). ${ }^{13}$ Formal review is the authority to assess whether a product of laws and regulations is formed by appropriate procedures according to the law, while material review is the authority to investigate and then evaluate whether the content of a legal product is in accordance with or contrary to the higher laws and regulations. ${ }^{14}$ Formal review and material review have different development histories, but the essence of the two terms is almost the same, namely for reviewing legal products. ${ }^{15}$

In the European tradition, there is a center in the review of norms. Kelsen argues that in a rule of law, it is very important to have a centralized review conducted by a specialized institution. Kelsen, who at the time played a role in the establishment of the Austrian constitution, tried to provide a special judicial review institution called the "verfassersgerichtshof" or Constitutional Court. ${ }^{16}$ Although prior to this idea, Austria had recognized the power to adjust disputes between citizens and the government regarding the protection of political rights, even to state courts, it had the power to decide constitutional objections made by citizens against state actions. ${ }^{17}$ However, the power lies with the Supreme Court of Austria, while Kelsen's idea was to establish a special institution, a Constitutional Court to conduct reviews of the products of the Law.

The 1945 Constitution has explicitly designed the distribution of authority to conduct judicial review in Article 24A paragraph (1) for the Supreme Court and Article 24C paragraph

12 Jimly Asshiddiqie, Hukum Acara Pengujian UndangUndang (Jakarta: Yasrif Watampone, 2004).

13 Maria Farida, Masalah Hak Uji Terhadap Peraturan Perundang-Undangan Dalam Teori Peraturan Perundang-Undangan: Seri Buku Ajar (Jakarta: FH. UI, 2000).

14 Ibid.

${ }_{15}$ Tim Penyusun Hukum Acara MK, Hukum Acara Mahkamah Konstitusi (Jakarta: Sekretariat Jenderal dan Kepaniteraan Mahkamah Konstitusi RI, 2010).

16 Jimly Asshiddiqie, "Sejarah Constitutional Review Dan Gagasan Pembentukan MK,” @merica Pacific Place (Jakrta, 2012).

${ }^{17}$ dkk Muchamad Ali Safaat, Hukum Acara Mahkamah Konstitusi (Jakarta: Sekretariat Jenderal dan Kepaniteraan Mahkamah Konstitusi RI, 2011).
(1) for the Constitutional Court. According to the provisions of Article 24A paragraph (1), it is emphasized, "The Supreme Court has the authority to hear at the level of cassation, to review laws and regulations under the law against the law, and has other authority granted by the law." Then in Article 24C paragraph (1) it is emphasized, "The Constitutional Court has the authority to hear at the first and last level whose decisions are final to review laws against the Constitution." The right to judicial review in Indonesia can be classified into two types, namely: First, the right to judicial review of the law against the Constitution, which is the authority of the Constitutional Court (see: the 3rd Amendment to the 1945 Constitution, Article $24 \mathrm{C}$ paragraph I in conjunction with Law No. 24 Year 2003 concerning the Constitutional Court, Article 10 paragraph I letter a). Second, the right to judicial review of laws and regulations that are lower in level or under the law (such as: Government Regulations, Presidential Decrees, Regional Regulations, etc.). According to the Regulation of Supreme Court No. I year 2004 article I paragraph (1), what is meant by the right to judicial review is "the right of the Supreme Court to assess the material content of laws and regulations under the law against laws and regulations that are higher, the right of judicial review."

\section{B. Policy Rules}

M. Solly Lubis states that what is meant by state regulations (staatregelings) are written regulations issued by official institutions, both in terms of institutions and in terms of certain officials. These regulations include Government Regulations in Lieu of Laws, Government Regulations, Presidential Regulations, Ministerial Regulations, Regional Regulations, instructions, etc. According to I Gde Pantja Astawa, these are called state regulations (staatregelings) or decisions in a broad sense (besluiten) which are divided into 3 (three) groups, namely Wettelijk regeling (laws and regulations), such as the Constitution, Government Regulations, Government Regulations in Lieu of Laws; Beleidsregels (policy rules), such as instructions, circulars, announcements and others; and Beschikking (determination), such as Decisions and others.

The Netherlands has a definition of Policy rules (beleidsregels), according to Bruinsma, 
which cannot be separated from the concept of 'beleid' which means managing and regulating based on principles and policies. This aspect concerns the highest planning. Beleid can also mean remembering all related aspects and providing solutions to problems. ${ }^{18}$

Policy rules cannot be categorized as an ordinary form of laws and regulations, according to the opinion of Jimly Asshiddiqie. ${ }^{19}$ For example, a circular letter from a Minister for his staff is not made in the form of a Ministerial Regulation. Jimly Asshiddiqie, in his book ${ }^{20}$ as quoting Michael Allen and Brian Thompson's opinion, says that policy rules or "policy rule" which can also be referred to as "quasi legislation" can be grouped into 8 (eight) groups, namely Procedural rules (regulations that are procedural), Prescriptive/ Evidential Rules, Commendatory Rules, Voluntary Codes, Interpretative (interpretation guide), Rules of Practices, Rules of Management, or Rules of Operation, Consultative Devices and Administrative Pronouncements, Instruction to Officials (orders or instructions, such as Presidential Instructions etc.).

Policy rules can be made in various forms of written documents such as orders or instructions, such as Presidential Instructions (Inpres), work guidelines or manuals; Terms of Reference (TOR), Work Design or Project Design, Technical Guidelines (juknis), Guide Books (guidance), Circulars, such as Bank Indonesia Circular Letters, Implementation Guidelines (juklak), and others.

Van der Vlies argues that policy rules in the Netherlands, which are mostly made by ministers, are not based on law. Examples of Ministerial Regulations, which are policy rules, include laws, circulars on taxes, subsidies regulations, circuits on foreigners, and circulars on the implementation of social welfare laws. Van der Vlies actually divided the policy rules from the Netherlands into two categories. Policy rules because of the authority to create beschking from the ministerial authority, to establish beschking in law. However, the law does not specify norms that ministers should take into account when making decisions. In general,

18 Clark David, Encyclopedia of Law and Society: American and Global Perspectives (Los Angeles: Sage Publications, 2007).411

19 Jimly Asshiddiqie, Perihal Undang-Undang (Jakarta: Rajawali Pers, 2010).

20 Ibid. policy rules apply because the authority to make other decisions is related to the authority arising from the Law on the state budget. This policy rule occurs because the policy rule is needed to facilitate the management of these funds in the context of the use of state budget funds ${ }^{21}$.

According to Victor Imanuel W. Nalle, ${ }^{22}$ the United States of America also regulates the policy provisions of the Administrative Procedure Act (APA). However, US policy rules are not as comprehensive as the AWB agreement. The policy does not explicitly mention the term policy rule because their AWB is with beleidregel requirements. However, any rule where the content of the policy is based on the Rules is a rule. The process of establishing rules is set out in section 551 (4) APA:

...the whole or a part of an agency statement of general or particular applicability and future effect designed to implement, interpret, or prescribe law or policy or describing the organization, procedure, or practice requirements of an agency and includes the approval or prescription for the future of rates, wages, corporate or financial structures or reorganizations thereof, prices, facilities, appliances, services or allowances therefore or of valuations, costs, or accounting, or practices bearing on any of the foregoing.

In practice, the government often uses policy rules as the legal basis for implementing policies. The policy rules made by the government are not in the form of one of the types of laws and regulations known in Article 7 of Law No. 12 Year 2011. However, in the implementation, policy rules often have the same binding power as laws and regulations. ${ }^{23}$

In Law Number 30 Year 2014 concerning Government Administration, it can be seen that there is a regulation of the concept of discretion. We

\footnotetext{
${ }^{21}$ I.C. Van der Vlies, Buku Pegangan Perancang Peraturan Perundang-Undangan (Jakarta: Penerbit Direktorat Jenderal Peraturan Perundang-Undangan Kementerian Hukum dan Hak Asasi Manusia RI, 2005), hlm.192

${ }^{22}$ Victor Imanuel W. Nalle, "Kedudukan Peraturan Kebijakan Dalam Undang-Undang Administrasi Pemerintahan," Refleksi Hukum 10, No.1 Tahun 2016, hlm.11

23 Ibid.
} 
know that the concept of discretion is inseparable from policy rules as a "product" of discretion.

Discretion is specifically regulated in Chapter VI of the Government Administration Law. Previously, Article 1 defined discretion as a decision and/or carried out by Government Officials to overcome concrete problems faced in the administration of government in laws and regulations that provide choices, do not regulate, are incomplete or unclear, and/or there is government stagnation.

\section{The Concept of Rule of Law}

The 1945 Constitution, as the Indonesian constitution, isthehighestlaw.Aftertheamendment of the 1945 Constitution, it was contained in the body surrounding the concept of a rule of law, which previously was only contained in the preAmendment interpretation of 1945. According to Carl Schmidt, constitution is a political decision from above. Therefore, constitution is the highest position in the legal system of a state. ${ }^{24}$

According to Willem Koninjnenbelt, there are four important elements of the idea of a rule of law, namely the government must respect human rights (grondrechten), government actions must be controlled by a judicial body that freely assesses the legality of the action (rechterlijke controle), government authority should not be centralized but transferred to various state organs, which are balanced and mutually supervise (machtsverdeling), and the exercise of governing power must be based on the authority granted by the Constitution or recognized laws (wetmatigheid van bestuur)..$^{25}$

The element that determines the authority to run the government or government affairs must consider that the government must be based on laws or laws and regulations. Otherwise, the law is considered invalid (ongeldig). In general, it can be explained that a rule of law (rechsstaat), as in the theory studied by John Locke and Montesquieu, aims that people in power do not use the power arbitrarily, because they need to provide direction to limit power. According to Bagir Manan, in the concept of a modern rule of law, the government

\footnotetext{
24 Widodo Ekatjahjana, Pengujian Peraturan PerundangUndangan Dan Sistem Peradilan Di Indonesia (Jakarta: Pustaka Sutra, 2008).

25 Philipus M. Hadjon, Pengantar Hukum Administrasi Indonesia.
}

has the responsibility to realize social justice and public welfare for the prosperity of the people. ${ }^{26}$

According to Frans Magnis Suseno, a democratic rule of law includes laws that guarantee human rights as the most important element, state institutions that exercise their respective powers always and only based on applicable laws, state functions which are carried out by institutions in accordance with the 1945 Constitution of the Republic of Indonesia, and an independent and impartial judicial body. ${ }^{27}$ Realizing democracy needs to go through the law, and still accommodate the sovereignty of the people. ${ }^{28}$

The rule of law is called rechsstaat. In Indonesia, the establishment of the state from the beginning was aspired by the founding fathers as a stateoflaw. UndertheThirdAmendmentofthe 1945 Constitution, Article 1 (3) affirms that "Indonesia is a rule of law." As a rule of law, the entire life of the nation and state must be in accordance with the provisions of law in Indonesia. According to Julius Stahl, the concept of a rule of law which he calls with the term "rechtsstaat" includes four main elements, namely: the protection of human rights; the division of power; the law supremacy; and the state judicial administration. Meanwhile, A. V. Dicey identifies three important characteristics in every state referred to by law as "rule of law", namely: the rule of law; equality before the law; fair and impartial process.

The fourth principle "rechtsstaat" developed by Julius Stahl can be combined with the third principle "rule of law" developed by A.V. Dicey to achieve the characteristics of the modern rule of law. On the other hand, through the International Commission of Jurists, the rule of law also includes, (1) the state which is subject to the law; (2) The government which respects individual rights and; (3) the justice which is free and impartial.

D. The Right to Review Policy Rules

The review of a legal norm is the enforcement of constitutional supremacy. According to Smith Bailey (UK), this judicial review exists on the basis of the Ultra Vires doctrine used in the British

\footnotetext{
26 dkk Jazim Hamidi, Teori Dan Politik Hukum Tata Negara (Yogyakarta: Tatal Media, 2009).

${ }^{27}$ Lukman Hakim, Eksistensi Komisi-Komisi Negara Dalam Sistem Ketatanegaraan Republik Indonesia (Malang: PDIH FH. Universitas Brawijaya, 2009).

28 Jimly Asshiddiqie, Hukum Tata Negara Dan Pilar-Pilar Demokrasi (Jakarta: Konstitusi Press, 2005).
} 
legal system. Yahya Harahap emphasizes that the judicial power grants rights and authority, namely everything that has not been delegated to the authorities, or the issuance of laws and regulations which are wider than what has been delegated, must be declared as an act that is not based on the law (illegal), because it is considered an unlawful act. Observing the limits of the government's authority to issue regulations that have been delegated. In accordance with the boundaries of jurisdiction or power, judicial power is given the right, function, and authority to supervise the Central and Regional Governors so as not to abuse power outside their authority.

In practice, Jimly Asshiddiqie says that the existence of three types of legal rules that can be reviewed are known or commonly referred to as control mechanism rules. Together these three constitute a form of legal basis as a result of the decision-making process in law, namely: (i) normative decisions containing natural arrangements (regeling), (ii) normative decisions containing an administrative determination (beschikking), and (iii) Normative decisions containing the nature of judgement. ${ }^{29}$

Bagir Manan ${ }^{30}$ is of the view "...that until now there is no agency that is authorized to resolve disputes that originate from a Policy Rule. In practice, objections to policy rules that cause harm are sued for unlawful acts." Sine ira et studio (it is understandable) that the absence of the court that can review policy rules (beleidregel) is based on the adage de rechter mag niet op de stoel van de administratie gaan zitten (judges may not sit on administrative chairs) which is closely related to the principle of separation of powers (machtenscheiding of machtenverding) in a rule of law (rechtsstaat) which is more or less influenced by the thought of separation of power from Montesquieu.

H. Abdul Latief states that the need for reviewing policy rules was based on two reasons, namely: ${ }^{31}$

29 Andryan, "Implikasi Putusan Hak Uji Materil Mahkamah Agung Terhadap Legalitas Pimpinan Dewan Perwakilan Daerah," Jurnal Penelitian Hukum De Jure 18, no. 3 (2018): 367-380.

3o Bagir Manan, "Masa Depan Peradilan Tata Usaha Negara", Dikutip Dari Ridwan, Diskresi... Hlm. 21., n.d.

${ }^{31}$ Abdul H. Latif, Hukum dan Peraturan Kebijakan (Beleidregel) Pada Pemerintahan Daerah (Yogyakarta: UII Press, 2005).
(1) Practical reason: driven by the need of both the government and the society. The society expects a guarantee of legal protection from the actions of government agencies or officials. On the other hand, the government agencies or officials need a limitation or a basis for not acting freely to establish policy rules that may conflict with laws and regulations and unwritten laws.

(2) Theoretical reason: drivenbythedevelopment of administrative law, especially the concept of besluit (decision) has received a new understanding that is quite broad and is the main instrument in the administration of a rule of law. Therefore, a judicial review of absolute policy rules must be carried out by the judicial institutions.

In practice, the Supreme Court has repeatedly conducted judicial review on legal products in the form of policy rules (beleidregel). The Supreme Court has reviewed policy rules in the format of circulars, decisions and regulations. The judicial review case started on January 30, 2009 when the SEPPMB was issued. As a result of the issuance of the Circular, the Regent of East Kutai which at that time was held by Ir. H. Isran Noor, M.S., objected and then submitted an application for a judicial review to the Supreme Court dated July 22,2009 which was received at the clerk's office of the Supreme Court on July 27, 2009 and registered with Number: 23 P/HUM/2009.

The SE PPMB material above is considered contrary to Law No. 4 Year 2004 concerning Mineral and Coal Mining (UU PMB), namely: "Insofar relating to the authority of the Regent which is conferred by Law, the provisions of Article 8 paragraph (1) letter b of the 2009 PMB Law expressly state: The authority of the Regency/ Municipal Government in the management of Mineral and Coal Mining, among others are:

$$
\text { c. ............ and so on.; }
$$

d. Granting IUP and IPR, fostering, resolving society's conflicts and supervising mining businesses in Regency/Municipal areas and/or sea areas up to 4 (four) miles;"

Based on the petition's plea for damages, the Supreme Court stated in its legal considerations that the SE PPMB was contrary to the applicable and higher provisions, namely the PMB Law, especially Article 8 paragraph (1) letter b and 
Article 173 paragraph (2), which are related to the authority of Regents in granting Mining Business License (IUP) and People's Mining License (IPR) so that the SE PPMB is invalid and not generally accepted and ordered the a quo Official (Minister of Energy and Mineral Resources) to cancel and revoke the SE PPMB. Regarding the object of the dispute, the Supreme Court in its legal considerations stated:

"...Whereas the object of the objection to the Judicial Review Rights is in the form of the Circular Letter of the Director General of Minerals, Coals and Geothermal, Department of Energy and Mineral Resources of the Republic of Indonesia Number: 03.E/31/ $\mathrm{DJB} / 2009$, although it does not include the sequence of laws and regulations as referred to in Article 7 of Law Number 10 Year 2004 concerning the Establishment of Laws and Regulations, but based on the explanation of Article 7 it can be classified as a valid form of laws, so that it is subject to the provisions of the order in which lower regulations must not conflict with the higher regulations (the principle of lex superior derogat legi inferiori).

Furthermore, based on the above considerations, the Supreme Court then affirmed as follows: "...Whereas based on these considerations it is proven that the Circular Letter of the Director General of Minerals, Coals and Geothermal, SE PPMB and the issuance of Government Regulations as the Implementation of Law Number 4 Year 2009 which is the object of the objection to the Judicial Review Rights (see Evidence P.1), is contrary to the higher regulations, in this case Law Number 4 Year 2009 concerning Mineral and Coal Mining."

The Supreme Court then issued a decision with a dictum, among others: granting the objection to the Judicial Review Rights from the East Kutai Regent as the applicant, declaring that the SE PPMB a quo contradicts the prevailing and higher provisions, namely Law Number 4 Year 2009, so that the Minister of Energy and Mineral Resources must cancel and revoke the SE PPMB. Referring to the ratio decidendi of the Supreme Court above, it is clear that the Supreme Court classifies the SE PPMB as laws and regulations so that it is subject to the principle of lex superior derogat legi inferiori.
The interpretation of the Supreme Court is mutatis mutandis based on the explanation of Article 7 paragraph (4) of Law No. 10 Year 2004 concerning the establishment of laws and regulations. The explanation of Article 7 paragraph (4) a quo states as follows: "Types of laws and regulations other than these provisions include, among others, regulations issued by the People's Consultative Assembly, the Constitution, the Supreme Audit Agency, Bank Indonesia, Ministers, Heads of Agencies, institutions, or commissions of the same level established by law or the government of the Province, the Governor, the Regency/Municipal Regional House of People's Representative, the Regent/Mayor, the Village Head or the equivalent."

The explanation of Article 7 paragraph (4) above shows that there is no logical explanation that explains that the 'Circular Letter' product is part of laws and regulations. The nomenclature used in the explanation of Article 7 paragraph (4) is 'regulation' in the sense of regeling, materially id est is also interpreted as legal rules that are in abstracto or general norms which are binding on the public (generally applicable) and their task is to regulate matters that are general in nature. While the nomenclature 'Circular Letter' is a form or format of a policy rule norm, materially id est is a product of State Administration officials on the basis of the use of discretionary authority (ermessen). Regarding this matter, Ridwan says that based on administrative law, Circular Letters (circulaire) are classified as policy rules (beleidregel), namely type of regulation whose authority to make them rests with the government on the basis of discretionary power.

The Supreme Court's jurisprudence shows that there is inconsistency in the review of policy rules on the basis of the laws governing the law. The Supreme Court's interpretation of its authority refers to the essence of the policy rules. If the subject is established as laws and regulations, the Supreme Court has the right to review it. In fact, the judicial review authority of the Supreme Court does not only refer to the content/substance but also to the form of the regulations. The main reference rule to determine laws and regulations is to look at the form or element which is defined as laws and regulations. ${ }^{32}$

32 Victor Imanuel W. Nalle, "Kewenangan Yudikatif Dalam Pengujian Peraturan Kebijakan,” Jurnal Yudisial 


\section{CONCLUSION}

Policy rules as a product of discretion. Discretion is an action taken by the government to overcome the legal vacuum as an effort to overcome the problem of government administration. The laws governing government administration in the Netherlands and the United States of America regulate how this discretion then leads to policy rules as its product. Policy rules as a product of discretion have a position in the Government Administration Law.

Article 1 of Law Number 30 Year 2014 concerning Government Administration defines discretion as a decision and/or carried out by Government Officials to overcome concrete problems faced in the administration of government in laws and regulations that provide choices, do not regulate, are incomplete or unclear, and/or there is government stagnation.

In Law Number 10 Year 2004 in conjunction with Law Number 12 Year 2011 in conjunction with Law Number 15 Year 2019 concerning the Establishment of Laws and Regulations, it is regulated that the Supreme Court cannot review policy rules, so that legal protection is needed for parties who are harmed as the result of the existence of a policy rule so that it can be in accordance with the concept of rule of law, as emphasized in the provisions of Law Number 28 Year 2009 concerning the State Administration which is Clean and Free From Corruption, Collusion and Nepotism and Law Number 30 Year 2014 concerning Government Administration.

\section{SUGGESTION}

There are many products of policy rules in supporting the administration of government, so the products of laws and regulations must prioritize the principles of rule of law and should be in accordance with the principles of proper governance. The decision of the Supreme Court that once made a breakthrough on the review of policy rules should be the basis and jurisprudence for the right to review policy rules. The strict regulation of the right to review policy rules will bring legal certainty to every action of government officials as in a rule of law.

\footnotetext{
6, no. $1(2013): 33-47$.
}

\section{ACKNOWLEDGMENT}

The researcher would like to express gratitude to all parties who have supported this writing, especially to colleagues at the Faculty of Law, Muhammadiyah University of North Sumatra.

\section{BIBLIOGRAPHY}

Abdul H. Latif. Hukum Dan Peraturan Kebijakan (Beleidregel) Pada Pemerintahan Daerah. Yogyakarta: UII Press, 2005.

Andryan. "Implikasi Putusan Hak Uji Materil Mahkamah Agung Terhadap Legalitas Pimpinan Dewan Perwakilan Daerah." Jurnal Penelitian Hukum De Jure 18, no. 3 (2018): 367-380.

Chandranegara, Ibnu Sina, Eka NAM Sihombing.

"EMERGENCY LAW-MAKING IN INDONESIA: BETWEEN POLITICAL AND CONSTITUTIONAL PROCESS." Journal of Legal, Ethical and Regulatory Issues 24, no. 4 (2021): 1-7.

Clark David. Encyclopedia of Law and Society: American and Global Perspectives. Los Angeles: Sage Publications, 2007.

Dias, RWM. Jurispredence. London: Butterworths, 1985.

Eka NAM Sihombing. "Menyoal Ketentuan Usul Pindah Pegawai Negeri Sipil Di Lingkungan Pemerintah Daerah Kabupaten Nias Barat." Jurnal Penelitian Hukum De Jure 16, no. 1 (2016): 95-104.

Ekatjahjana, Widodo. Pengujian Peraturan Perundang-Undangan Dan Sistem Peradilan Di Indonesia. Jakarta: Pustaka Sutra, 2008.

Farid Wajdi,Andryan. "Sifat Putusan Impeachment Mahkamah Konstitusi Terhadap Status Hukum Presiden Dan/Atau Wakil Presiden.” Jurnal Penelitian Hukum De Jure 20, no. 3 (2020): 301-313.

Farida, Maria. Masalah Hak Uji Terhadap Peraturan Perundang-Undangan Dalam Teori Peraturan Perundang-Undangan: Seri Buku Ajar. Jakarta: FH. UI, 2000.

Gayo, Ahyar Ari. "Optimalisasi Pelayanan Bantuan Hukum Bagi Masyarakat Miskin.” Jurnal Penelitian Hukum De Jure 20, no. 409-432 (2020). 
HR, Ridwan. Hukum Administrasi Negara. Jakarta: Rajagrafindo Persada, 2006.

I.C. Van der Vlies. Buku Pegangan Perancang Peraturan Perundang-Undangan. jakarta: Direktorat Jenderal Peraturan PerundangUndangan Kementerian Hukum dan Hak Asasi Manusia RI, 2005.

Jazim Hamidi, dkk. Teori Dan Politik Hukum Tata Negara. Yogyakarta: Tatal Media, 2009.

Jimly Asshiddiqie. Hukum Acara Pengujian Undang-Undang. Jakarta: Yasrif Watampone, 2004.

- Hukum Tata Negara Dan Pilar-Pilar Demokrasi. Jakarta: Konstitusi Press, 2005.

- Perihal Undang-Undang. Jakarta: Rajawali Pers, 2010.

- "Sejarah Constitutional Review Dan Gagasan Pembentukan MK.” @merica Pacific Place. Jakrta, 2012.

Lukman Hakim. Eksistensi Komisi-Komisi Negara Dalam Sistem Ketatanegaraan Republik Indonesia. Malang: PDIH FH. Universitas Brawijaya, 2009.

Manan, Bagir. "Peraturan Kebijakan" (n.d.): 1617.

Muchamad Ali Safaat, dkk. Hukum Acara Mahkamah Konstitusi. Jakarta: Sekretariat Jenderal dan Kepaniteraan Mahkamah Konstitusi RI, 2011.

Pardede, Marulak. "Legitimasi Pemilihan Kepala/Wakil Kepala Daerah Dalam Sistem Pemerintahan Otonomi Daerah." Jurnal Penelitian Hukum De Jure 18, no. 2 (2018): 127-147.

Philipus M. Hadjon. Pengantar Hukum Administrasi Indonesia. Yogyakarta: Gajah Mada University Press, 1993.

Soeprapto, Maria Farida Indrati. Ilmu PerundangUndangan: Jenis, Fungsi dan Materi Muatan. Yogyakarta: Kanisius, 2010.

Tim Penyusun Hukum Acara MK. Hukum Acara Mahkamah Konstitusi. Jakarta: Sekretariat Jenderal dan Kepaniteraan Mahkamah Konstitusi RI, 2010.

Victor Imanuel W. Nalle. "Kedudukan Peraturan Kebijakan Dalam Undang-Undang
Administrasi Pemerintahan.” Refleksi Hukum 10, no. 1 (n.d.).

_. "Kewenangan Yudikatif Dalam Pengujian Peraturan Kebijakan.” Jurnal Yudisial 6, no. 1 (2013): 33-47.

Bagir Manan, "Masa Depan Peradilan Tata Usaha Negara", Dikutip Dari Ridwan, Diskresi... Hlm. 21., n.d.

\section{Laws and Regulations}

The 1945 Constitution

Law Number 12 Year 2011 in conjunction with Law Number 15 Year 2019 concerning the Establishment of Laws and Regulaitons

Law No. 24 Year 2003 concerning the Constitutional Court

Law Number 4 Year 2009 concerning Mineral and Coal Mining

Law Number 30 Year 2014 concerning Government Administration 